\title{
LEBON RÉGIS/SC, DA VIVÊNCIA CABOCLA NO CONTESTADO AO SUFOCAMENTO NA LÓGICA AGRÁRIO-CAPITALISTA
}

\author{
Lebon Regis/SC, de experiencia cabocla en el contestado a la asfixia en la lógica agrario- \\ capitalista
}

\author{
Émerson Dias Oliveira \\ Universidade Estadual de Londrina \\ cooperativismopopular@hotmail.com \\ Nilson Cesar Fraga \\ Professor Adjunto do Depto. De Geografia da Universidade Estadual de Londrina \\ nilsoncesarfraga@ hotmail.com
}

Artigo recebido em 18/08/2016 e aceito para publicação em 14/09/2016

DOI: $10.12957 /$ tamoios.2016.25152

\begin{abstract}
Resumo
O processo de desbravamento, ocupação e povoamento da região Sul do Brasil, deu-se numa particularidade secundária ao formato tradicional das demais regiões colonizadas. Nessa região, o Estado de Santa Catarina surge ainda como território de ocupação posterior aos demais estados sulistas, uma espécie de espaço periférico e "abandonado" entremeio os extremos da Estrada de Ferro São Paulo - Rio Grande. Entre os rudimentares povoados surgidos, está a atual Lebon Régis/SC, integrando uma região conhecida como - Contestado -, sendo que esta região é tida como deficitário de uma territorialidade racional e "civilizada" aos olhos das classes dominantes dos séculos XIX e XX. Na segunda década do século XX, a região do Contestado padece em seus domínios uma guerra civil camponesa de proporções extremamente devastadoras, uma revolução que é na realidade o estopim de um choque de classes já vigente há algum tempo. Assim, seus residentes seculares - o caboclo - imbuído em sua fé messiânica, resistiram e lutaram até o seu completo genocídio contra as instituições públicas e privadas, uma fatalidade em que a lei do mais forte (poder e capital) se impôs ao mais fraco (caboclo), uma barbárie por muitos anos legalizada, justificada e legitimada pelo Estado, sendo o foco deste ensaio trazer à tona a realidade dos fatos, oportunizando ao caboclo de Lebon Régis sua expressão identitária de fato.
\end{abstract}

Palavras chaves: Lebon Régis; Contestado; Caboclo; Fé.

\section{Resumen}

El proceso de compensación, liquidación y ocupación del sur de Brasil tuvo una función secundaria en el formato tradicional de otras regiones colonizada. En esta región, la provincia de Santa Catarina sigue apareciendo como el territorio de la ocupación posterior a otras provincias del sur, una especie de espacio periférico y " arrinconados " extremos de inserción de ferrocarril de Sao Paulo - Rio Grande. Entre los pueblos que surgen rudimentarios, es la corriente Lebon Régis / SC, que es parte de una región conocida como - Contestado - y esta región es considerada como deficiente en una territorialidad racional y " civilizada" a los ojos de las clases dominantes de los siglos XIX y XX . En la segunda década del siglo XX, la región Contestado sufre en sus dominios proporciones de una guerra civil campesina muy devastadoras, una revolución que es en realidad el gatillo de choque de clases ya existente durante algún tiempo. Por lo tanto , sus residentes seculares - el caboclo imbuido en su fe mesiánica, resistieron y lucharon hasta el total genocidio en contra de las instituciones públicas y privadas, una fatalidad en la que se impuso la ley de lo más fuerte (el poder y el capital ) en la más débil ( el caboclo ), una barbarie durante muchos años legalizado, justifica y se legitima por la provincia, que es el foco de este ensayo sacar a la luz la realidad de los hechos, proporcionando oportunidades para el caboclo de Lebon Régis su expresión identidad de hecho.

Palabras clave: Lebon Régis; Contestado; Caboclo; Fe. 


\section{Introducão}

A relação do homem com a terra sempre foi um dos principais elementos constituintes da sua formação identitária, um processo que é diuturnamente construído e reconstruído em decorrência das territorialidades que são sobrepostas ou até mesmo resgatadas no espaço vivencial do indivíduo, culminando nas distintas singularidades características de todo e qualquer que seja o território analisado.

Ciente dessa relação que o sujeito apresenta com seu território e principalmente do enorme esforço que este tem, visando garantir sua sobrevivência e manutenção em seus domínios, expressos na forma de luta e resistência frente aos avanços das "novas e modernas" territorialidades, que constantemente lhe conflitam visando uma nova caracterização desse terreno pretérito, este estudo visa demonstrar as metamorfoses que se dão no espaço geográfico em decorrência desses confrontos territoriais, pois, a consecução do território é, antes de tudo, fruto do conflito, impregnado de poder, algo que se encontra na essência do ser humano.

O recorte a ser estudado está inserido na região do Contestado, localizada entre os estados do Paraná e Santa Catarina, palco de uma Guerra Civil Camponesa de proporções federativas, um conflito que é na realidade a efetivação de uma nova territorialidade sob as práticas vivenciais aplicadas nos campos e vilas pelos caboclos então presentes (viventes). Essa região ${ }^{3}$ passou a ser conhecida pelos colonizadores a partir de 1641, ano em que por lá passou o primeiro grupo de bandeirantes paulistas a caminho do Rio do Grande do Sul (ROSSETO, 1989).

Esse cenário é expresso como uma espécie latente de dizimação de um modo de vida vivo, uma manobra da nova territorialidade que utiliza-se de todas as formas possíveis - persuasão ideológica, intervenção política entre outros intentos perversos e, neste caso, principalmente da intervenção militar e de luta armada -, em que a verdadeira intencionalidade foi unicamente a aniquilação das práticas antigas, incluindo-se a própria existência do sujeito em prol de uma nova lógica a serviço do capital, numa percepção totalmente contraditória e adversa ${ }^{4}$.

Este estudo ocorre por meio de uma análise dos processos territoriais intrínsecos aos domínios da região do contestado, a partir da ótica do atual município de Lebon Régis/SC (Mapa 1), considerando que este é integralmente inserido nos contextos da formação territorial da região e apresenta-se como testemunha material e imaterial do mundo vivido e sentido no decorrer do último século. 


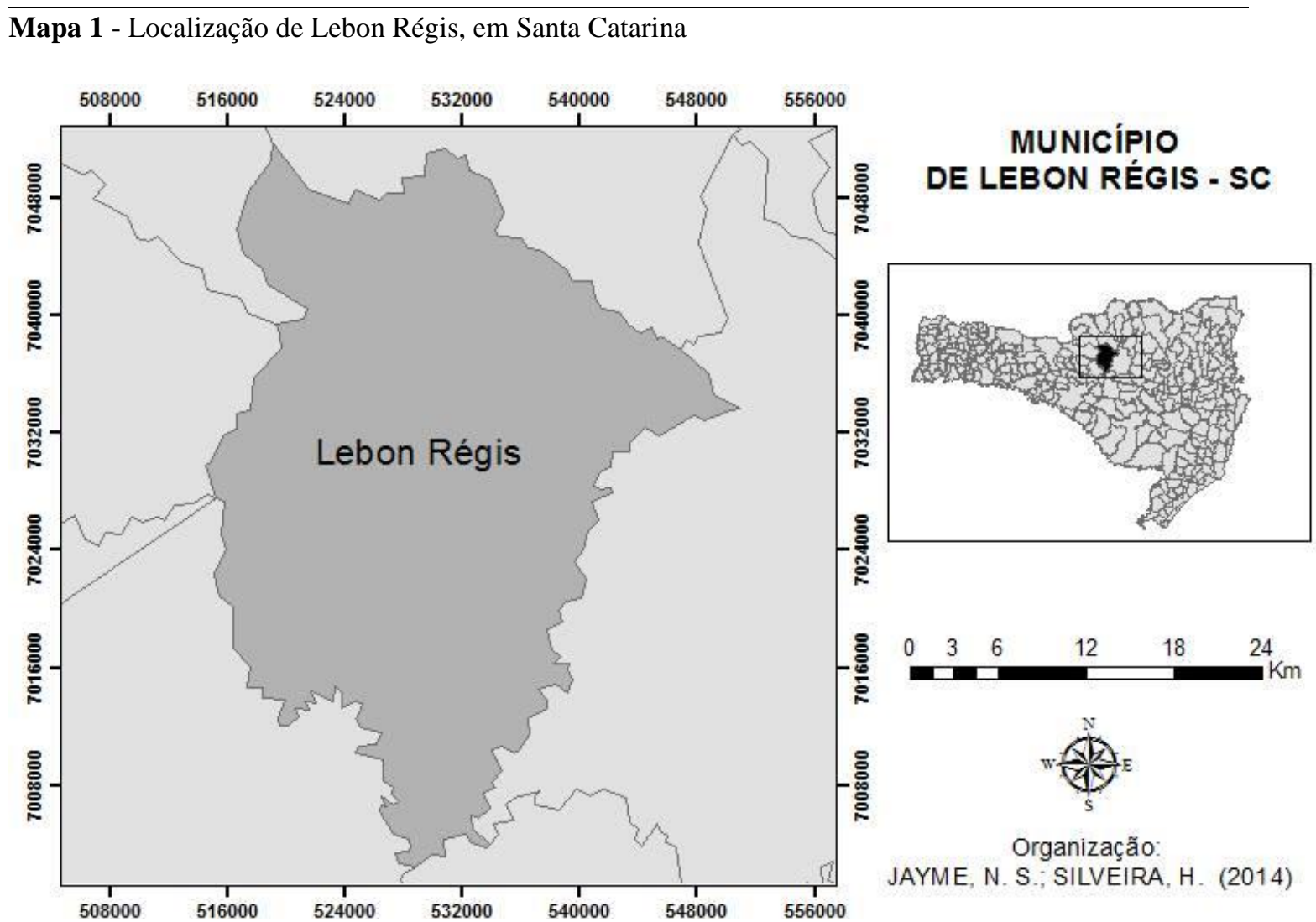

As análises se dão desde a virada do século XIX para o XX, com as particularidades anterior e posterior a guerra, a emancipação política do município de Lebon Régis/SC e as novas lógicas inseridas com a última passagem do milênio, uma investigação que integra os elementos socioeconômicos vigentes, de manutenção da vida cabocla, os valores refletidos e absorvidos ao longo do tempo e as novas consolidações implementadas pelo capital agrário.

Tendo em mente a superficialidade ${ }^{5}$ e principalmente os fatos e acontecimentos distorcidos que são elencados a respeito do litígio entre os camponeses e o poder público-privado do Contestado, este ensaio objetiva por meio de uma análise histórica das interferências e implicações sociais nos arredores dos atuais domínios municipais lebon-regenses, verificar as ações que a transição dos territórios caboclos para a terra de negócio (agronegócio) refletiu e alterou no vivido dos sujeitos ainda presentes nestes lugares.

Esta discussão, a partir da escala de um município modelo, representativo no conjunto regional caboclo do Contestado, serve de base para as ideias que se desenvolvem sobre a relação espaço-tempo-território, sobre as temporalidades e sobre a problemática do desenvolvimento territorial lebon-regense a partir de um aspecto teórico-metodológico que é marcado por uma análise histórico-crítica, relacional, multidimensional sobre o território caboclo enquanto, também, resistência secular a tentativa de extermínio daquele povo e, sua cultura identitária. A relação temporalespacial se fecha com a realidade vivida contemporaneamente, mas para que se possa entender esse mundo atual lebon-regense e do Contestado, há que se levantar e diagnosticar a preterida região da Guerra do Contestado, depois disso, as nuances dos quatro anos da guerra civil cabocla e, por fim, os reflexos desse passado secular sobre o mundo vivido atual, pois a atual sociedade é uma mescla de todo o processo de formação socioespacial pré-capitalista e capitalista. 


\section{O Contestado como memória e reflexo caboclo}

A singularidade e complexidade que está envolvida neste capítulo da historiografia nacional são de tamanha magnitude que assusta nas primeiras vistas e contatos que os leitores e pesquisadores realizam sobre essa temática ainda pouco visível nos níveis regionais e federais. O litígio deu-se, oficialmente, no período de 1912 a 1916, resultando na morte de milhares de homens e mulheres dispersos numa área de aproximadamente 25 mil quilômetros quadrados. Esse cenário apresenta-se na realidade como o ponto culminante de um enfrentamento social que já discorria deste o início do século XVIII, por meio das primeiras intersecções históricas dos nativos com os colonizadores europeus, isso por volta de 1720, quando o bandeirante Zacarias Dias Cortes chegou até o Rio Inhanguera, atual Rio Chapecó (ROSSETO, 1989).

Em um território onde imperava além da insegurança jurídica, institucional e partidária destas terras "Contestadas" 6 " por Paraná e Santa Catarina, diversas outras particularidades ali imperam de maneira que o clímax do conflito expande os domínios locais e passa a ser (re)conhecido inclusive em outros espaços continentais. A esse respeito Lemos (1983, p.98) comenta que;

\footnotetext{
De todos os movimentos havidos nestes sertões, nenhum teve importância tão grande, quanto o da revolta dos sertanejos da área contestada pelos Estados do Paraná e Santa Catarina; foram mais de 3 anos de lutas, em que se envolveram mais de 20 mil pessoas, em que o governo teve que mandar mais de 13 expedições militares, inclusive 4 aviões, os quais pela primeira vez no mundo, estreavam a serviço da guerra. A região conflagrada abrangia 70 léguas de sertão bravio e florestas de difícil acesso, onde os fanáticos se concentravam em "redutos" ou vilas disseminadas pelo território.
}

Vários foram os motivos do conflito armado, a exploração madeireira nos moldes capitalistas, a colonização da região por novas levas de imigrantes, a expulsão de posseiros ali enraizados por gerações, as disputas políticas entre coronéis em concomitância a um movimento messiânico de solidez e dimensão cultural amplamente interiorizado na vivência cabocla, culminando na sua integralização como sujeito que visava guardar, manter e garantir o seu modo de vida secular naquele território (FRAGA, 2010, p. 139).

Apesar das várias singularidades e nuances humanas presentes neste contexto histórico-territorial, o choque (subjugamento) do caboclo frente às imposições autoritárias e arbitrarias inseridas nas suas comunidades é o elemento principal do litígio. Estes sujeitos ainda hoje apontados nos atos abstratos ou não - repressivos - em desordeiros e impedindo o "progresso" social, continua oculto, invisível e silenciado no seu direito cidadão, (sobre)vivendo uma secular vitimação comunal alheia a qualquer política efetiva para sua emancipação e dignidade social.

Para Schüller (2000), o surgimento e formação dos sujeitos que habitavam as terras contestadas são oriundos da mestiçagem entre os europeus, mouros e nativos ${ }^{7}$ da região nessa zona meridional, um contingente populacional que antecede a errônea noção de comunidade nórdica constituinte desse território, sendo que estes imigrantes são implantados somente em períodos posteriores por meio das políticas institucionais na passagem para o século XX, ou seja, o ideário de um território com origem nas famílias alemãs, italianas e polonesas, entre outras, deu-se somente depois de concluída a guerra, isto é, depois de ter sido executado o projeto de "limpeza da área".

Conforme Lemos (2006), a elaboração basilar do mosaico humano no contestado tem participação de negros ${ }^{8}$, apesar de terem seu número pouco numeroso nas regiões meridionais, em particular, no planalto serrano. Outro caractere que estava 
interiorizado neste povo deve-se a ferocidade e bravura herdada dos Kaigang e dos Xokleng, chamados de belicosos pelos paulistas, pontuando a têmpera do caboclo da região. A influência moura nos territórios ibéricos também se fez sentir nos domínios coloniais destes últimos, culminando em traços étnicos que agregou os aspectos culturais dos grupos humanos que constituiu o caboclo do contestado;

O homem do Contestado não é o nômade dos pampas gaúchos, embora tenha a mesma origem etimológica, porquanto um e outro sofreram as influências do meio. O gaúcho, com traje beduíno vaga sobre as coxilhas que emprestam a mesma sensação dos elevados do deserto e das ondas que encrespam o maroceano. O caboclo do Contestado foi criado entre frondosas araucárias (...) formaram os dois - caboclo e gaúcho - dois tipos étnicos distintos, o que lhes emprestou tipos humanos singulares. (...) O beduíno tem como Senhor o Universo, enquanto que o caboclo tem como Senhor a Confraria o Messianismo. Ambos não admitem as desigualdades nas relações sociais, porque todos são irmãos, vivem do mesmo modo, usam as mesmas vestes e consomem os mesmos alimentos. Desprezam as fortunas, porque a opulência e a riqueza não são títulos de uma confraria. (SCHÜLLER, p. 28, 2000).

O Observatório do(s) Centenário(s) da Guerra do Contestado, mantido na Universidade Estadual de Londrina (UEL) coordenado pelo pesquisador Nilson Cesar Fraga $(\mathrm{CNPq})$ dedica-se a vários estudos e inferências a estes sujeitos subjugados de suas raízes e de seu pertencimento (FRAGA, p. 01-26, 2015);

O habitante da região do Contestado é mescla de muitos grupos humanos, de diferentes origens. Pode-se dizer ainda que a "diferenciação entre o serrano do campo (ligado à pecuária) e o do mato (ligado ao extrativismo), até hoje não está estudada, sequer esboçada" [...] [...] São descendentes dos tropeiros, de refugiados "farroupilhas" de 1835-1945, de "federalistas" de 1892-1894; são enfim, os mateiros, "gente do mato", mais ligados à lavoura ou à criação de suínos. Pouca pecuária. Pinheirais fechados engordavam com pinhão silvestre os porcos no inverno. No verão outros frutos alimentavam as "criadeiras". Cultivavam a moranga e a abóbora. Alimentavam-se à base de milho. Dos monjolos tiravam a farinha, a quirera e o cuscuz. Poucas ervateiras. Ranchos de pinho em paus roliços e ranchões. Cozinha de fogo no chão sem trempes de ferro. Esses homens não tiveram professores, e muito menos escolas; não tinham médicos e utilizavam a medicina caseira; a religião era tradicional (principalmente pautada no catolicismo rústico do interior do Brasil) e avoenga, pois os padres não apareciam, ou muito raramente o faziam naqueles sertões.

A prática de menosprezar e ignorar as culturas indígenas no Brasil em detrimento da valorização da moda eurocêntrica justificava a dizimação do nativo. Entretanto, sem os saberes e vivências indígenas teria sido impossível a ocupação do território colonial, elementos esses essenciais que "identifica o caboclo da região de Curitibanos, síntese inexorável da mistura étnica que se sobrepôs às diferenças de origem e perenizou a herança indígena nas gerações subsequentes" (LEMOS, p. 68, 2006).

Segundo a autora, os paulistas descendem dos primeiros portugueses que dedicavam-se as explorações nas terras campeiras interiorizadas, acabaram se fixando nesses domínios e mesclando aos nativos. Assim, esse mestiço numa espécie de metamorfose cultural intercalada entre as matas de araucárias e erva-mateiras, configura o sujeito que territorializou de maneira alheia, feliz e despreocupada as vilas e comunidades do Contestado até a propagação das barbáries profetizadas pelo Santo Monge ${ }^{9}$ José Maria. 
Lemos (2006), aborda a formação cultural do caboclo do Contestado com especial enfoque aos integrantes da região de Curitibanos/SC, abarcando os atuais domínios do município de Lebon Régis ${ }^{10} / \mathrm{SC}$, até então participantes das mesmas fronteiras e ainda habitados pelos mesmos indivíduos;

Tais seres humanos não considerados a princípio, sofrem a opacidade do não reconhecimento. Não sendo reconhecidos, não existem enquanto sujeitos. A identidade negada pelo dominador é uma espécie de anulação, de coisificação do humano, convertido em besta de carga, força de trabalho não remunerado, mais um elemento contido na terra para ser explorado (LEMOS, p. 69, 2006).

O caboclo de Lebon Régis, assim como as comunidades em arredores tiveram sua consolidação no lugar por intermédio de um construto social extremamente dificultoso, um processo em que cada palmo de chão envolvia verdadeiras guerras pelo seu domínio. Essas frentes de expansão ${ }^{11}$ atuaram na realidade como os verdadeiros desbravadores desses sertões, sendo posteriormente vítimas de um literal genocídio em decorrência de interesses perversos dos setores públicos e privados. As frentes de expansão paulista ocorrem por volta de 1777 em Lages e, inclusive por posseiros já a partir de 1790 (Thomé, 1981).

Um diagnóstico da realidade das territorialidades vigente na região de Lebon Régis na transição do século XIX para o XX foi expressa por Vieira da Rosa (p. 01, 1918), que atuou na região de Curitibanos, apontando "ligeiramente as suas múltiplas riquezas," trazendo uma vaga noção daquela paisagem e a relação da população cabocla com o ambiente da região:

Município serrano, Curitibanos é, apesar disso, mais nemorensis do que campesino, porem, mesmo nessas mattas, que nenhum ponto de contacto têm com as florestas virgens do littoral, que tem um caracter subtropical, pascem os gados bovino e cavallar, criam-se manadas abundantes de porcos. É que essas mattas, limpas de cipós, gramadas, permittindo passear por ellas a Cavallo, como nalgum parque europeu, os fructos nutritivos são abundantes, entre os quaes os guamirins, o vacul, as goiabas serrana, os araçàs a imbuia, 0 pinhão, as amoras e o butiá, constituem o alimento principal para a engorda dos de suinos $\mathrm{O}$ butiá vegeta expontaniamente numa área não muita dilatada: começando apparecer junto à Villa, nos campos de Antonio Sampaio. A descripçào que fizemos dos terrenos curitibanenses explica: primeiro o modo de vida do caboclo que, tendo a creação de porcos como sua principal e unica industria era obrigado a viver pelos ermos, no meio das mattas; segundo, a difficuldade que as forças do governo encontraram nas marchas e no serviço de intendencia. Vimos acima que os terrenos comprehendidos entre o Marombas e o Correntes, formam uma bella região campesina bordada de capões. Estende-se desde a barra do Timbó, Corrente ao Jusante, até à confluencia do Marombas com o Grande e magestoso Canoas. No ponto de bifurcação, porem, e isso numa extensão de meia légua, os campos desapparecem para dar lugar a uma frondosa matta de pinhaes e palmeiras. Entre o Correntes e o Rio do Peixe, toda essa grande extensão curitibanense, com excepção dos Campos de Butiá Verde, os das Perdizinhas e Perdizes, gramados e um ou outro campestre, como o da Liberata e do Serro de Pedra, do Cahapiá, etc, é coberta de matto. O caracter da vegetação altera-se cada vês ao aproximar-se do Rio do Peixe onde apesar da existência dos pinheiros e imbuias, já apparecem especies que habitam a região littoral, de caracter subtropical; e o que acontece com os vegetaes tambem succede aos animaes, encontrando-se ali especies que só encontramos nas mattas da costa. Os terrenos limpos, de campos, são todos propriedades de ricos fazendeiros que, cuidando tambem da lavoura, possuem outras terras no que chamam serras, terras de matto. Para os de Guarda Mor e para todos os que ficam situados ao 
sudoeste da Villa, essas terras de planta estão nas mattas da margem direita do Correntes, excelentes para todos os cultivos, sem exceção.

Conforme relatos do Capitão Vieira da Rosa, Curitibanos como um dos mais importantes palcos da guerra, era visto como um dos locais mais pobres e esquecidos de Santa Catarina, carente de uma estrutura e logística econômica e ainda do terreno acidentado com seus grandes rios dificultando a comunicação (VIEIRA DA ROSA, 1905, p. 264-265). Como em todos os processos de constituição populacional, o Contestado também teve essas adversidades, uma realidade em que praticamente inexistia qualquer fomento governamental efetivo para o "local".

Os caboclos conviveram com as adversidades próprias do isolamento local, limparam os caminhos e vilas por intermédio do árduo trabalho braçal e toscas ferramentas, impossibilitando a utilização de áreas territoriais extensas, dada a abundância de cursos hídricos e o abrupto relevo acidentado. Mafra (2008), cita os aspectos socioeconômicos locais como de uma agricultura de subsistência ${ }^{12}$ para o suprimento alimentício das comunidades locais e dos tropeiros. As culturas predominantes destacavam-se o milho, o feijão entre outras, aparecendo também o pinheiro que garantia a sobrevivência das comunidades com seus frutos (pinhão).

Entretanto, todo esse contingente populacional de caboclos de Lebon Régis e das demais localidades da região, dotadas de valores culturais enraizados em tradições camponesas na manutenção da vida, pobre e inculta aos olhos da elite agráriocapitalista, vivendo de seus roçados manuais, da criação de porcos, da extração da ervamate, do tropeirismo de carga e dos trabalhos temporários nas fazendas dos coronéis ${ }^{13}$ que começam a se implantarem nesse território, vivenciariam uma mudança radical no formato de sociedade que até então viviam.

O município de Lebon Régis, possuidor de toda essa mescla socioambiental e cultural regional secular, tem uma história muito mais recente no que tange sua autonomia política. Segundo o sitio da Prefeitura Municipal (PMLR, 2016) e, oficialmente, por volta de 1895 chegavam aos campos e matas do município os primeiros moradores vindos de várias comunidades catarinenses e paranaenses. Entre os pioneiros, ou primeiros habitantes, da terra se destacavam Francisco de Souza, Nicolau Spautz, Miguel Spautz, Joaquim Pereira, Artur Barth e Alfredo de Almeida Mello. A história lebon-regense está ligada às primeiras fazendas localizadas na Serra da Boa Esperança (FRAGA, 2016), introduzidas pelos ditos desbravadores paulistas, isso após a conquista dos campos de Curitibanos, do Corisco e de São João. Já no século XIX, as sesmarias possibilitaram a formação de alguns núcleos por causa do isolamento da região, mas tiveram um parco desenvolvidos.

Em 1903, na parte noroeste da atual sede municipal, foi criado o distrito de São Sebastião da Boa Vista, sendo que, somente trinta anos depois, o distrito foi elevado à categoria de vila, com o nome de Caraguatá e, em 1950, passou a ser chamado de São Sebastião do Sul. Ao mesmo tempo, na parte sul, na região conhecida pelos antigos moradores, por Trombudo, formou-se outro núcleo que levou, ao longo do tempo, os nomes de Salto do Rio dos Patos, Fazenda do Salto e, depois, como Santo Antônio do Trombudo - para a população mais antiga, Trombudo ainda representa a cidade. Foi esse, um núcleo mais fácil de progredir, pois era um local de passagem de tropeiros que faziam os caminhos Curitibanos-Caçador. O arraial de Santo Antônio do Trombudo tornou-se distrito em 1934 (PMLR, 2016).

Em 1938, o distrito de Lebon Régis passou a categoria de vila e, a partir daí, foi se desenvolvendo e a população aumentando, tornando-se um entreposto importante e, desta forma em 19 de dezembro de 1958, conjuntamente com o distrito de São Sebastião do Sul, fora criado o município de Lebon Régis, com sede neste último. Em 
janeiro de 1959, o então Governador Irineu Bornhausen instalou o novo município. $\mathrm{O}$ nome do município foi uma homenagem ao catarinense General Gustavo Lebon Régis, que, por ocasião da Guerra do Contestado, era Secretário Geral do Estado de Santa Catarina e traçou o primeiro ataque a Taquaruçu, um dos maiores redutos de caboclos do Contestado (PMLR, 2016). Com quase 60 anos de vida política emancipada, esse município catarinense ainda não promoveu colóquios e debates passíveis de questionarem o nome que herdou com a emancipação, cuja nomenclatura foi enviada, arbitrariamente e diretamente, da capital do estado. Nesse caso, há que se refletir sobre a dignidade do povo lebon-regense, pois, ao entoar o nome do Coronel Lebon Régis, estão, esses cidadãos, fazendo perpetuar o poder dos vencedores, sobre os caboclos e caboclas vencidos na Serra Acima catarinense - ou seja, por quanto tempo um povo que foi usurpado e massacrado é capaz de carregar o nome de um dos representantes das oligarquias políticas da época? Até quando o povo do Trombudo exaltará um nome oficial que representa o sangue dos seus antepassados? Essas contradições são se resumem a esse município, elas estão espalhadas por todo o território do Contestado, passados mais de 100 anos do crime de guerra registrado nessa porção de terras do Sul do Brasil.

\section{Lebon Régis - um sertão "desconhecido" apropriado e subjulgado economicamente}

As intencionalidades e interesses que a Guerra do Contestado ${ }^{14}$ despertam vão desde a dificuldade diária vivida pelo caboclo (insignificante e ignorada) em decorrência dos implementos capitalistas que chegavam à região, até o genocídio legitimado pela ideia de nacionalismo-militar que se consolidava, considerando a plena vigência da Primeira Guerra Mundial, em curso naquela época. Assim, o Contestado com seus povoamentos, entre eles Lebon Régis, visto como um espaço secundáriorudimentar, desvalorizado e carente de uma "luminosidade" racional-civilizatória surgiu como um molde perfeito para as instancias públicas e privadas intervirem - astutamente, perversamente e arbitrariamente - sem qualquer represaria político-social, considerando o contexto temporal-espacial.

Nesse sentido, a guerra se apresenta apenas como um instante em que a exploração e subjugação do caboclo atingem um patamar de saturação tão instigante e absurdo que a própria sobrevivência destes sujeitos passaram a serem comprometidas, em que todo um construto vivencial foi violado em prol das vontades do capital externo que avançava pela região. Lebon Régis não ficou a margem destas barbáries, foi inclusive um dos principais palcos de conflitos que se dariam na região.

O município de Lebon Régis, que é emancipado de Curitibanos/SC, tendo desta feita seu processo histórico alinhado similarmente a este último, tem sua origem com a presença de sertanistas de Curitiba/PR, os quais utilizavam trajetos do planalto catarinense para chegarem até a bacia do rio Itajaí e a costa do litoral catarinense Lemos (1983, p. 46). Assim, por serem originários dos "Campos de Curitibanos", surgem a partir do povoamento de Curitibanos. Localizado, hoje, no Meio-Oeste do estado de Santa Catarina, mesorregião Oeste Catarinense, Lebon Régis pertence à microrregião do Alto Vale do Rio do Peixe ${ }^{15}$, tendo sua emancipação dada em 1958, por intermédio da Lei Estadual n. ${ }^{\circ}$ 380, com o desmembramento do município de Curitibanos/SC. Apresenta uma área de 940,656 $\mathrm{km}^{2}$, localizado a uma latitude $26^{\circ} 55^{\prime} 44^{\prime \prime}$ Sul e a uma longitude 50\%4'43" Oeste, estando a uma altitude de 980 metros (IBGE, 2010). O relevo predominante é de planície. Distinguem os solos cambissolos e neossolos, caracterizados pela boa fertilidade natural, com pedregosidade frequente e profundidade 
média. A base da economia é a agricultura que corresponde $65 \%$ da movimentação econômica total, a indústria e o comercio $35 \%$, dentre outros. O uso das terras do município apresenta flutuações temporais, sendo um processo extremamente dinâmico. Interferem principalmente as políticas agrícolas em vigor, circunstancias de mercado e as condições climáticas.

O município tinha uma população estimada em 12.105 habitantes ${ }^{16}$ no ano de 2015, apresentando um IDHM (2010) - Índice de Desenvolvimento Humano Municipal de 0,649. O estado de Santa Catarina utiliza ainda como metodologia de análise o IDMS ${ }^{17}$ - Índice de Desenvolvimento Municipal Sustentável -, uma ferramenta com viés na sustentabilidade focando o desenvolvimento equilibrado das dimensões sociocultural, econômica, política e ambiental, apresentando, Lebon Régis, nesse caso, 0,563 como índice referencial (PMLR, 2016).

Com fortes características com o povoamento da região, Lebon Régis também tem seus primeiros habitantes por intermédio da fixação do caboclo ao seu lugar, ou seja, os caboclos são a gênese da formação social, quando se excluí os ocupantes originais, nesse caso, os indígenas - Frente de Expansão -, somente após esse período desbravatório é aparece à figura do Estado e do capital consolidado, numa recorrência temporal que se estende entre os séculos XVII e início do XX. Esse processo posterior é chamado por Martins (p. 74-75, 1980) de Frente Pioneira;

\begin{abstract}
Um segundo movimento é constituído pela forma empresarial e capitalista de ocupação do território- é a grande fazenda, o banco, a casa de comércio, a ferrovia, a estrada, o juiz, o cartório, o Estado. É nessa frente que surge o que em nosso país se chama hoje, indevidamente, de pioneiro. São na verdade os pioneiros das formas sociais e econômicas de expansão e dominação vinculadas às classes dominantes e ao Estado. Essa frente pioneira é essencialmente expropriatória porque está socialmente organizada com base numa relação fundamental embora não exclusiva, que é a de compradores e vendedores de força de trabalho.
\end{abstract}

Nesse período de sua historicidade, Lebon Régis já havia presenciado três processos de territorialização distintas - o nativo/originário, o caboclo e agora a fazenda capitalista integrada à estrutura urbana -. Assim, o município oriundo da adequação do caboclo a lógica das primeiras fazendas localizadas na Serra da Boa Esperança, introduzidas pelos bandeirantes paulistas é representado numa nova sistemática estrutural que, aliado ao extrato-social da guerra, culminará nas expressões humanas que vagueiam estes domínios até a contemporaneidade - dando, ao lebon-regense, uma alma cabocla, hoje, independente da origem étnica e do período de chegada dos seres humanos que passaram a habitar aquela região.

Considerando a região como imprópria para o cultivo da cana-de-açúcar e do café e precária em minerais, a mesma era tida como devoluta, sendo esta cedida ao bom grado e gosto das elites regionais em sesmarias. Aos caboclos restava se estabelecerem em terrenos periféricos aparentemente sem dono, construindo seus ranchos e roçados. Entretanto, "subitamente surgia um homem rico portando o título que conseguira na véspera, expulsando-os e ainda se utilizando do fruto de seu trabalho. Ou o pequeno lavrador arrendava essa parcela, plantando principalmente milho e feijão" (FERREIRA FILHO, 1978, p. 75).

A consolidação populacional de Lebon Régis se constitui, ainda, nos séculos XVII e XVIII por meio das sesmarias de invernadas, sendo a região conhecida então por "Pouso dos Curitibanos", dada as áreas de gramíneas que permitia o pouso, descanso e engorda do gado vindo do Sul, durante o período do Tropeirismo. Desta feita, a região ganha, aos poucos, proeminência econômica, desenvolvendo agriculturas de 
subsistência e rústicos serviços, incentivados pela possibilidade de ganho com a chegada de novas tropas (RITTER, 1980).

\begin{abstract}
Na medida em que os encostos se transformavam em pousos, o local atraia para suas proximidades outro posseiro, concorrente, que também construía seu rancho e fazia surgir novo pouso. Como historiou Arinos, “(...) fincado o pouso, logo surgia nas suas imediações um ou outro morador, erguendo palhoça, acomodando criações, plantando milho e passando a negociar com os homens das tropas que ali pernoitassem. Prosperando, montava venda, abastecia-se do melhor" (1921, p. 111). A abertura da venda, ou bodega, era o sinal de que aquele pouso prometia ser bom. E aí, vinha um terceiro homem, e os ranchos cresciam, passando a ser chamados de estalagens. Encostos, pousos, hospedarias, bodegas, fazendolas, com potreiros ou currais, eram as atrações aos tropeiros viajantes, alguns dos quais vieram a escolher a região para nova moradia. Fixando-se, promoviam o aparecimento de núcleos populacionais e, assim, no decorrer do tempo, fizeram surgir às primeiras povoações, mais tarde vilas, no Espaço Livre do Contestado (THENÓRIO, p.12, 2012).
\end{abstract}

Esse processo teve tamanha importância que vai além do surgimento de novos lugares, estradas e vilarejos. As tropas xucras percorreram verticalmente o sertão catarinense por quase duzentos anos, conduzindo muares dos pampas aos muladeiros do vale do Paraíba, onde eram comercializados. O economista Celso Furtado coloca esse período como o "Ciclo do Tropeirismo "18", com uma abrangência em nível continental, que deve tal existência em virtude do arrebentamento de animais "xucros" nos sertões sulistas pelos bandeirantes, visto que, uma;

[...] gadaria vivendo à gandaia, à lei da natureza, sôlta em campos ferazes, sem restrições e sem dono, como um presente régio a esperá-los. Nada mais lucrativo para quem andava à cata de mercadoria vendável do que arrebanhar cavalos e éguas, burros e bêstas, bois e vacas para vendê-los, a bom preço, nas regiões carentes dêsses animais (GOULART, 1961, p. 35).

A máxima que se têm do tropeirismo como sendo uma atividade genuinamente de tradição gaúcha é errônea, haja vista que os domínios da região do Contestado, entre eles Curitibanos, tiveram participação fundamental nesse ciclo econômico, inclusive vindo a serem utilizadas para a implantação de fazendas para a procriação de muares, bovinos e, ainda, tropas de porcos em períodos próximos, processo esse que enraizou-se em locais cada vez mais internos da região do Contestado, na entrada dos anos 1900 - nessa época, os Porcadeiros tiveram um grande papel na economia e fixação populacional regional.

A tradição extrativista da erva-mate no Contestado também teve suas beneficies com a intensificação do tropeirismo, pois os cargueiros, também característicos nas tropas, potencializou o desenvolvimento da indústria do mate no interior da região, realizando o transporte desde os armazéns, em que os ervateiros depositavam o produto da extração, ou desde os rudimentares barbaquás, aos engenhos nas vilas, com destaque para Curitiba e Joinville e, destas para embarque nos portos oceânicos. Esse intenso "vai e vêm" das tropas das regiões interioranas aos centros urbanizados funcionava como o único, e mais eficiente, meio de comunicação de toda a região (THENÓRIO, 2012).

Assim como o gado, o porco também chega às terras tupiniquins por volta do século XVI por intermédio de Martim Afonso de Souza, na capitania de São Vicente, sendo que ambos se popularizaram pelo resto da colônia com sua domesticação e procriação com a inserção nas florestas nativas. Assim, as manadas de porcos ${ }^{19}$ também 
chegam à região de Curitibanos no planalto catarinense, engrossando o comércio das tropas de porcos conduzidas pelos Porcadeiros;

Vivendo em um ambiente rico em fontes de alimento, as porcas poderiam ter grandes ninhadas, com mais de dez bacorinhos, o porco era um animal de grande fertilidade e de custo baixo, pois para seu trato não se necessitava de nada além dos recursos disponíveis. "Porco era que nem rato", dizia Altino Bueno da Silva (2005), antigo morador da região do Vale do Rio do Peixe, sobre a abundância do animal na região. Para Valdomiro Monteiro (2010), nascido em Curitibanos, "o porco criava à toa no mato, comendo fruta. Nasci em 1935, tinha muito porco naquela época, todo mundo tinha porco, criava nos terrenos dos vizinhos, dos fazendeiros" (BRANDT, p. 303-322, 2015).

O ciclo tropeiro de animais como gado, muares e porcos, aliado ao já tradicional ouro-verde do Sul, a erva-mate ${ }^{20}$ (illex paraguariensis), atuava no sentido de uma lógica do capital local, através de pequenos aportes financeiros de fazendeiros, mas a parte mais significativa desse ciclo dava-se em decorrência do esforço e do trabalho dos primeiros povoados caboclos com seus roçados de subsistência e serviços sazonais aos grandes fazendeiros, na extração do mate, condução de tropas e serviços rústicos da lida diária.

As particularidades dos sujeitos ${ }^{21}$ de Lebon Régis e de todo o Contestado, conhecido e divulgado, estava apenas começando. O professor Eleutério Nicolau da Conceição em sua obra "A Saga do Contestado - Histórias de Santa Catarina - em Quadrinhos", esboça de maneira simples e direta algumas fatos que, de fato, se deram nesse contexto, uma realidade que pode ser visualizada simplificadamente conforme a Figura 01 a seguir, envolvendo distintos e diversos interesses (Estado, Capital e o Povo).

Figura 1: O Contestado: A cultura cabocla e as perversidades público-privadas.

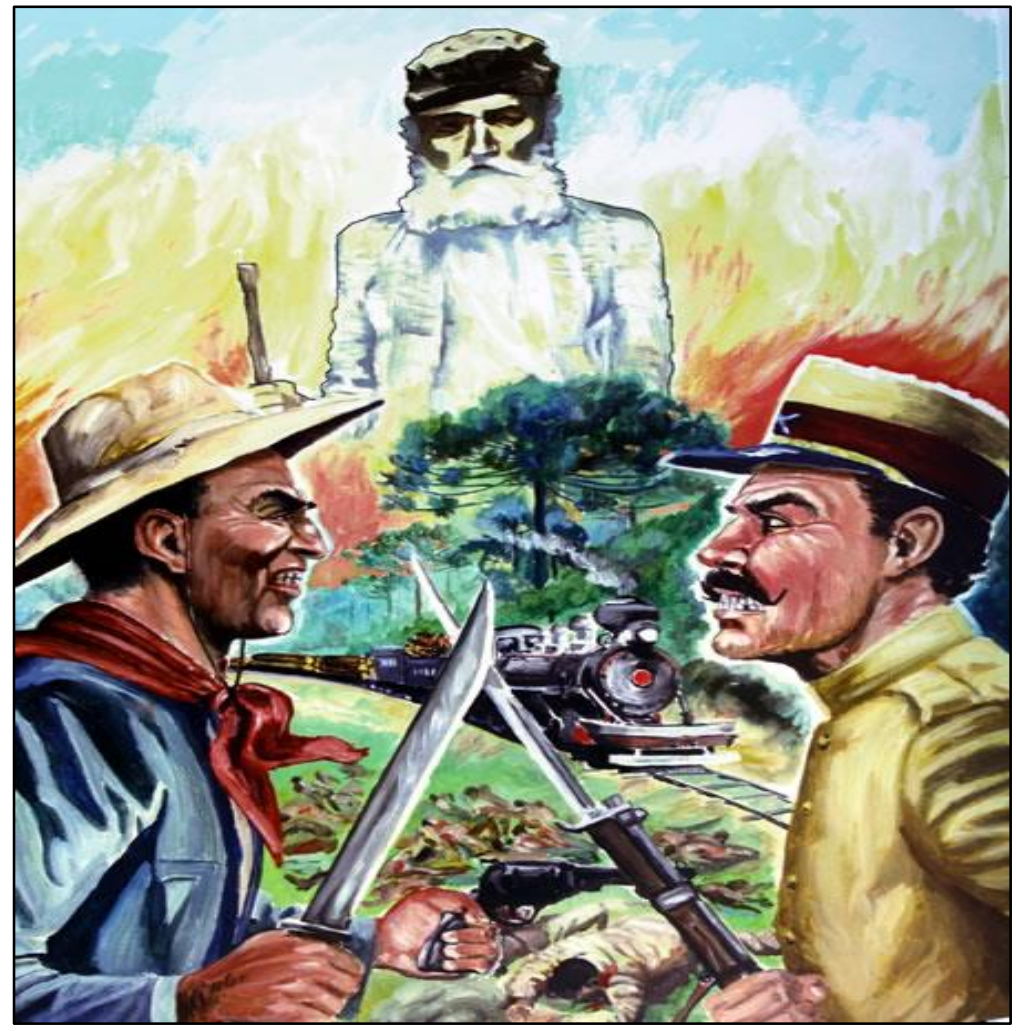

Fonte: Conceição (2004) 
Entretanto, um novo período se iniciava na região, previamente profetizada pelos Monges, desde 1870, chegaram os tempos do "Dragão de Aço" - locomotiva -, dos "gafanhotos de aço" - aviões utilizados na guerra -, "viria um besouro de aço para acabar com a mata" e também "a cobra preta que mata gente", se referindo a motosserra e ao asfalto, respectivamente (SALOMÃO, 2012). Assim, no início dos 1900, chega à região o empreendimento que cumpriria todas as profecias messiânicas dos Monges - a Estrada de Ferro São Paulo-Rio Grande, uma estrutura sabiamente apontada por Fraga (2015), que estava alheia a qualquer realidade socioeconômica e cultural vigente no interior desses extremos.

O tropeirismo, a extração do mate e do pinhão cede seu espaço para a passagem dos trilhos, alterando drasticamente a vida local. O problema inicia-se com a concessão de $15 \mathrm{~km}$ em cada margem da ferrovia, uma área onde habitava um povo secular - o povo caboclo -, domínios totalmente desrespeitados. Não satisfeitos, instalase na região a maior madeireira da América Latina na época - Lumber Company ${ }^{22}-$, visto que essas terras eram cobertas por milhões de pinheiros araucária, imbúias, canelas pretas, cedros e cabriúvas, numa área de 3.248 km² (FRAGA, 2015).

Esse processo de exploração madeireira segue intenso até meados da década de 1960, quando, na região, surgem os primeiros focos de reflorestamento comercial, uma lógica mercantil que graças à "limpeza ética" da guerra, dizimou todo e qualquer processo de resistência aos interesses capitalistas. Na década de 1970 dá-se o esgotamento da floresta, sendo que a saída é a procura de outras frentes pioneiras, um processo que será similarmente aplicado pelos empresários sulistas e o governo na região Amazônica, considerando que restava agora, ao opaco planalto catarinense, apenas um bolsão de miséria, conforme (LUDKA \& FRAGA, p. 13, 2015);

Em síntese, a região do Contestado se caracteriza como um enorme bolsão de miséria em Santa Catarina, isso não é diferente na parte que coube ao Paraná depois da "partilha" do território, no acordo de 1916, que "colocou fim" numa guerra genocida de pobres não-brancos - a Guerra do Contestado. A guerra foi maldita, ceifou milhares de vidas camponesas por interesses do capital e dos coronéis da época, gerando, 100 anos depois do seu início, um território maldito, marcado pela maldição das políticas públicas ineficientes, corruptas e de interesses de pequenos grupos que dominam a região, em todas as escalas.

Enfim, o município de Lebon Régis é, na atualidade, um depositário de sujeitos pobres que pagam um passivo social resultante dos desmandos historicamente perpetrados pelo interesse estatal a serviço do privado, refletindo numa demanda social não apenas concreta, mas na impossibilidade da vivência do caboclo, uma subversão de valores tão ignorante e divergente de autonegação do sujeito, sucumbidos num nevoeiro de ostracismo, invisíveis e incapazes de resgatarem sua identidade cabocla ${ }^{23}$. Mas, nos últimos anos, nesse município, há todo um processo de empoderamento da cultura cabocla em construção pela sociedade, envolvendo, desde o poder público, professores, estudantes e as comunidades, até agentes externos. Isso tem se dado por meio de atividades festivas e culturais ou em trabalhos de (re)descoberta do patrimônio material e imaterial lebon-regense, além da restauração e salvaguarda de alguns patrimônios e sítios históricos contidos no território municipal (Figuras 2 e 3). 
Figura 2 e 3: Grupo de Ação de São João Maria na restauração do Crematório de Cadáveres de Perdinhas, fevereiro de 2016 e Cavaleiros do Contestado de Lebon Régis, na Missa Cabocla de encerramento da I Semana do Contestado, de Lebon Régis, julho de 2015.
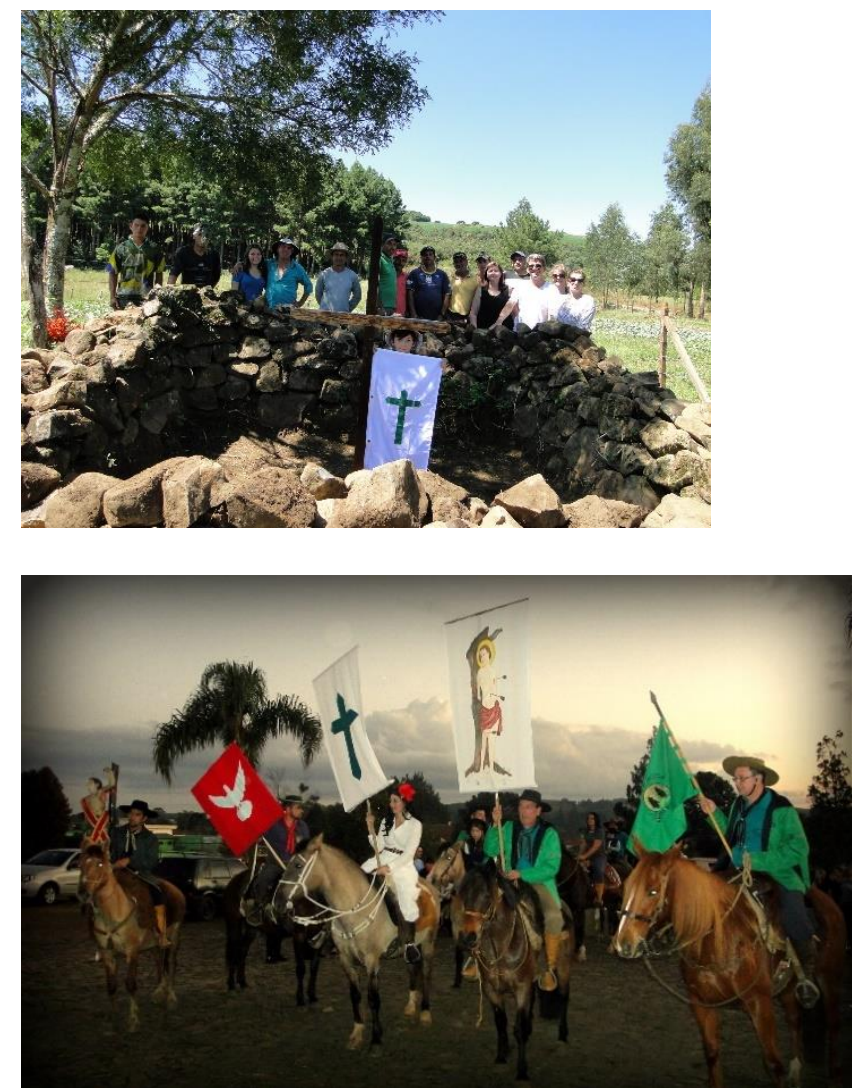

Fonte: Acervo de Nilson Cesar Fraga - Observatório do(s) Centenário(s) da Guerra do Contestado/UEL (2016).

O Grupo de Ação de São João Maria, vem desvelando os fatos e sítios históricos da Guerra do Contestado e da cultura cabocla no território municipal. Há, hoje, desde apresentações de dança, feiras escolares, eventos pelas comunidades interioranas e na sede, até a aprovação de uma lei municipal de tombamento dos bens matérias, imateriais e ambientais. Nesse sentido, o município dá um grande passo em prol da valorização da cultura ancestral dos seus habitantes.

\section{$\underline{\text { A realidade (in)contestada a ser (re)contestada em Lebon Régis }}$}

Um lugar hoje esquecido entre suas memórias, as vezes contraditórias, dentre a culpa e epopeia dos seus antepassados e, marcado pelo desinteresse do poder púbico, notadamente o estadual e o federal, essa é a Lebon Régis atual, uma cidade dos caboclos "invisíveis" e oprimidos, em que, sequer, a lembrança de luta e bravura de seu povo foi preservada, considerando que o opressor, até esse direito negou a estes sujeitos. Esta é a cidade do político, do militar e do general Lebon Régis, que tão bem representa a história oficial, a dita história dos vencedores, o caboclo aí não tem vez, não tem voz e não tem vida. O antigo povoado ao sul de Curitibanos de Salto do Rio dos Patos, Fazenda do Salto e depois como Santo Antônio do Trombudo, foi dizimado em 100 anos de história regional, isso por meio de um processo que sempre procurou uma maneira de legitimar a intervenção público-privada, com a falsa promessa do desenvolvimento social da região - ao povo do Trombudo, resta continuar lutando pela vida e esperando por um futuro melhor, pelo futuro de felicidade, isso como herança 
secular advinda das falas do Monges que acalentaram os corações caboclos trombudenses.

Analisar a paisagem de Lebon Régis atual é remeter aos conhecedores e desconhecedores desse território fatos ocorridos no passado e suas marcas no presente, sempre pensando que o território atual, é uma herança da formação socioespacial, uma certa reflexão singular e complexa dos processos territoriais que ali se sobrepuseram e dão as feições atuais, uma cara cabocla, cheia de dignidade, de um povo que luta secularmente, para existir, antes de tudo, no seio da sua própria comunidade. Hoje, numa quase deserto verde ${ }^{24}$ e calmo de pinus, parece esboçar entre suas silhuetas cartesianas de troncos e galhos, as ações e movimentos estratégicos de um caboclo completamente conhecedor e "dono" de seus domínios, que tinha (e tem) a fé, a resistência e a luta camponesa como única saída para continuar sendo "caboclo", num mundo imaginário, cujas paisagens do passado, povoam a mentes dos habitantes de Lebon Régis (Figura 4).

Figura 4: Paisagem típica do interior de Lebon Régis - a araucária, o campo e o cavalo -, São Sebastião do Sul, maio de 2015.

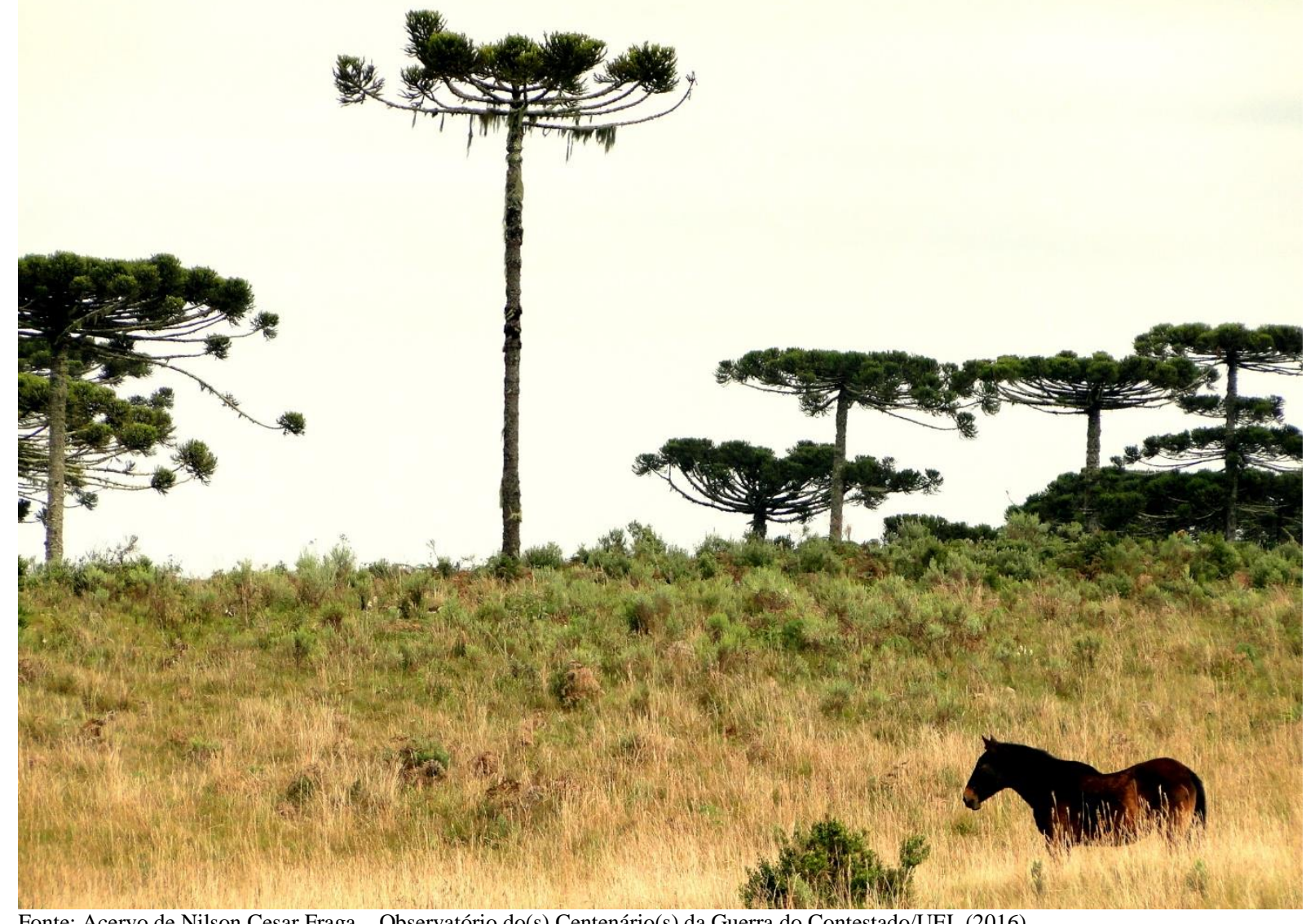

Fonte: Acervo de Nilson Cesar Fraga - Observatório do(s) Centenário(s) da Guerra do Contestado/UEL (2016).

Os reflexos de uma ocupação agroexportadora e fomentada pelo capital externo retira (toma) da região as riquezas naturais, sem qualquer retorno ou compensação aos sujeitos locais, resultando num total descaso de abandono e exploração. Os reflexos são aferidos por parâmetros institucionais que evidenciam claramente uma realidade abusada e violada de seus direitos sociais, como podem ser 
visíveis na Lebon Régis um século posterior a entrada do capital, sobretudo estrangeiro, na região.

As análises de dados estatísticos oficiais, que seguem, demonstram e dão um panorama sobre a realidade lebon-regense e a herança de pertencer ao Contestado e estar entre as municipalidades mais carentes do estado de Santa Catarina, pois, ao longo dos últimos 100 anos, o território e o povo dessa terra foi explorado por capital externo e, por conta disso, a riqueza foi tirada do município, deixando muito pouco dessa fortuna distribuída entre a população local.

O município apresentava no censo de 2010, 5.689 habitantes na zona urbana e 4.316 habitantes na zona rural, uma realidade que demonstra seu baixo grau de urbanização, caracterizando pela baixa oferta de empregos urbanos. Carente de uma dinâmica socioeconômica, o município se "sobressai" nos seus monocultivos, uma situação que nada agrega socialmente ao lugar.

Conforme dados da Secretaria Municipal de Agricultura local (2014), o município possui 1.410 famílias de agricultores - produtores. A economia baseia-se na pecuária e agricultura, destacando-se as produções de cereais milho 17.760 toneladas, em 3.700 hectares, feijão 5.250 toneladas em uma área de 2.500 hectares, trigo 1.800 toneladas em 750 ha e soja 216 toneladas em 90 ha, na horticultura com produção em grande escala de tomate 4.000 toneladas em 80 ha, cebola 18.250 toneladas em 730 ha, alho 210 toneladas em 35 ha, fumo 330 toneladas em 185 há, na bovinocultura de corte com rebanho de 19.370 cabeças, bovinocultura de leite com rebanho de 925 cabeças com a produção de 825 mil litros, fruticultura maçã com 988 há plantado produzindo $32.110 \mathrm{tn}$, entre outros culturas que vem inovando a casa dia.

Conforme dados do $\operatorname{MDS}^{25}$ (2016), no município de Lebon Régis, o total de famílias inscritas no Cadastro Único ${ }^{26}$ em novembro de 2015, era de 2.566, dentre as quais: 622 famílias com renda per capita familiar de até $\mathrm{R} \$ 77,00,600$ famílias com renda per capita familiar de até $\mathrm{R} \$ 154,00,874$ famílias com renda per capita até meio salário mínimo e 470 famílias com renda per capita acima de meio salário mínimo.

Recepcionando perfeitamente esses dados, têm-se o Índice de $\mathrm{GINI}^{27}$, que apresenta o valor de 0,462, uma realidade bem concentradora da renda, considerando a propagação dos monocultivos latifundiaristas presentes no município. Em 2006, Lebon Régis possuía um PIB per capita da ordem de $\mathrm{R} \$ 7.413,23$, colocando o município na $256^{a}$ posição do ranking estadual, valores bem distantes da média do Estado e do Brasil, respectivamente $\mathrm{R} \$ 21.214,59$ e $\mathrm{R} \$ 12.688,28$.

Em buscas no banco de informações do MDS (2016), o Programa Bolsa Família (PBF) beneficiou, no mês de janeiro de 2016, 1059 famílias, representando uma cobertura de $95,9 \%$ da estimativa de famílias pobres do município. As famílias receberam um valor médio de $\mathrm{R} \$ 141,16$. Num cálculo simples, considerando o montante de famílias inscritas no Cadastro Único - 2.566 famílias -, multiplicadas por uma média (não muito pessimista) de quatro integrantes por núcleo familiar, têm-se um total de aproximadamente dez mil pessoas, de um montante estimado, pelo IBGE, em 12.105 habitantes no ano de 2015.

Outra situação que ajuda a demonstrar a baixa qualidade de vida do município é o Índice de Desenvolvimento Humano Municipal, onde se constatou que o índice 0,649 apresentado por Lebon Régis, foi 10,58\% menor que o índice de Santa Catarina e 4,05\% menor que o índice brasileiro no mesmo período. O censo 2010 aponta, ainda, dados da incidência de pobreza ${ }^{28}$ municipal, o município de Lebon Régis possuía a incidência de $4,5 \%$ da população com renda familiar per capita de até $\mathrm{R} \$$ $70,00,20,4 \%$ com renda familiar per capita de até 1/2 salário mínimo e 51,8\% da população com renda familiar per capita de até 1/4 salário mínimo, ou seja, existem em 
Lebon Régis situações de extrema pobreza, isto em plena região Sul do país, parte do Estado-Nação tão prepotente e arrogante frente aos demais domínios da nação.

Como falar em "vida cabocla" em um domínio que apresenta uma taxa de mortalidade infantil de 32,3 óbitos para cada 1.000 nascidos vivos, enquanto que a média catarinense e brasileira era de respectivamente 12,6 e 16,4 óbitos para cada 1.000 nascidos vivos em 2006, esse é o cenário que os diversos ciclos e tipos de exploração deixaram em Lebon Régis, um lugar onde seu sujeito apenas "sobrevive" (IBGE, 2010).

De maneira geral, Lebon Régis continua ainda sendo um espaço a serviço do capital, com seus monocultivos, serviços rústicos e políticas de compensação social, um domínio em que seus integrantes "sem vozes" são literalmente domados por uma minoria elitista. Não seria exagero comparar seus habitantes com as infinitas varas de porcos que cortaram seu chão ainda no século XIX, visto que estão jogados a própria "sorte", uma sorte que se mostra cada vez mais penosa e longe de garantir um mínimo de condição de vida digna.

Entretanto, como dever e compromisso da ciência, este ensaio se apresenta não como solução ou fórmula acabada para interferência numa dada realidade, pois a ciência não é ação, ela é reflexão, um refletir que situa o sujeito em seus mundos. Assim, este estudo direcionado por meio da vivência cabocla, atua no sentido de materializar a ideia do agir nesses elementos humanos, ação esta que só será possível com a iniciativa do próprio caboclo se posicionar como tal, se fazer sentir e se fazer existir e exigir dos poderes públicos, sobremaneira os estaduais e federais, o pagamento da dívida histórica deixada pela Guerra do Contestado e pelo capital de exploração do seu território.

Enfim, considerando os enfrentamentos contemporâneos que o capital impõe ao caboclo, de forma cada vez mais perversa, essa resistência e luta carece de ser fomentada e agregada ideologicamente da autoajuda pregoada ainda no início do século XX pelo Monge: "quem tem, mói, quem não tem, mói também, e no fim todos ficarão iguais", um espírito corporativo em que a audácia e a criatividade do caboclo surpreendia as forças imensamente superiores que invadiram seus domínios.

\section{Consideracões Finais}

Independente da nomenclatura que se atribui aos sujeitos do Contestado caboclos, fanáticos, jagunços, facínoras, rebeldes, estes brasileiros foram massacrados e dizimados numa espécie de mensagem bem esclarecida àquela sociedade, ficando evidente que movimentos e iniciativas daquelas envergaduras não deveriam jamais ser seguidos por um povo que primava pelo "progresso social e o bem comum do indivíduo". Na prática, o que ocorre é um território tomado e manuseado estritamente ao interesse do capital externo, um domínio ignorado de seus valores e subjugado a externalidades distantes e divergentes da região.

As análises e pesquisas realizadas no recorte espacial de estudo evidenciam uma Lebon Régis esquecida e distanciada de iniciativas que sejam realmente do interesse público, com o enfoque no caboclo local. A região como um todo (Contestado) além de ter sido dizimada por agentes de outras territorialidades, sofreu com a introdução em seus (ex)domínios, com a partilhas de terras com o ideário de branqueamento civilizacional do povo (imigração européia), um descaso vergonhoso e vexatório com o caboclo, refletindo nos dados de exclusão social apontados anteriormente.

Apesar de Lebon Régis ser um município com relativo tempo de existência (1958), não é visível nele ainda uma política real de resgate social dos seus integrantes, 
considerando que sua maioria sobrevive na pobreza, uma problemática expressa no vivido desses sujeitos, seja na sua estrutura material ou imaterial, haja vista, a fragilidade, desgaste e dissolução identitária destes, os quais muitas vezes, até envergonham-se de posicionarem-se como remanescentes do "Exército Encantado de São João Maria", antes tão imponentes, destemidos e bravios nos sertões contestados.

Antes de uma efetiva compensação social, pelo já secular processo de massacre e exploração a que os caboclos de Lebon Régis ainda são submetidos, faz-se necessário além do acesso a sua terra de sonhos e felicidades - uma herança dos tempos de guerra -, a edificação de uma vida com dignidade para os que vivem, hoje, nesse município, pois eles (os habitantes de hoje) precisam de "vida", moradia, saúde, dignidade, enfim, de respeito a sua pessoa, ao seu povo, a sua memória, ao seu modo de vida, ou seja, é latente a falta de iniciativas e ações públicas que contribua para que Lebon Régis, efetivamente, seja habitada por cidadãos de direitos.

Por meio deste ensaio, foi possível construir uma análise, por intermédio da historiografia da Guerra do Contestado, a qual se apresenta distorcida e contraditória no meio social, negando a voz e vez do caboclo como sujeito-social, sintetizado por fatores de ordem étnica, econômica, cultural e política e condensado na sua trajetória existencial ainda pouco explorada e explicitada aos catarinenses e brasileiros. Mas, acima de tudo, as análises geográficas são contundentes e doloridas, ao mostrar uma sociedade que perambula nas margens de terras ricas do povo Barriga Verde, carregando os índices mais baixos do desenvolvimento humano entre os catarinenses. Assim, esse diagnóstico científico, pautado a partir da demanda e lógica do caboclo invisível, tem como propósito não um construto terminado e rígido apenas pelas análises frias da ciência geográfica, mas, permeando, até onde foi possível, pelo mundo vivido caboclo. Mas, visa antes de tudo, abrir e possibilitar novos caminhos investigativos, nos quais ele mesmo poderá, posteriormente, ser (re)pensado, como já vem se repensando e empoderando o povo caboclo do Trombudo do Contestado (Lebon Régis) nesse últimos anos, sobretudo ao realizar eventos que enobrecem a cultura cabocla da qual fazem parte, repensando e rompendo contradições que estavam no seio da sociedade, que ligavam os caboclos aos jagunços contratados para matá-los, separando-se, cada vez mais, dos jagunços, orgulhando-se de ser caboclo. Pois o caboclo sempre fora do bem, queria o bem e fazia o bem, mas, ao ser atacado, defendeuse com toda sua força e sua fé, na manutenção da sua sociedade secular, que estava territorializada sobre as florestas de araucárias e campos da Serra Acima.

\section{$\underline{\text { Notas }}$}

${ }^{3}$ Os primeiros grupos humanos a penetrarem em territórios de Santa Catarina foram grupos caçadores e coletores, que teriam atingidos a região através do Rio Uruguai por volta de 5.500 a. C. Posteriormente, o litoral, em face dos amplos recursos alimentares de que dispunha, teria servido como pólo de atração, abrigando populações diversificadas e por um longo período de tempo. O povoamento do litoral iniciou-se praticamente até a chegada dos grupos europeus. Os grupos humanos pescadores e coletores, pré-ceramistas foram substituídos por grupos ceramistas talvez agricultores por volta de 1.000 a. C. (BACK apud SANTOS, 1973, p. 28).

${ }^{4}$ Relatos da imprensa na época (...) "existiam milhares de pobres caboclos", na grande maioria "fugitivos, foragidos, bandoleiros, pistoleiros, malfeitores, fanáticos, jagunços, bandidos", que levantaram seus facões e espingardas na Guerra do Contestado (1913-1916). Ninguém se referia a esta "gente" como se fossem simples moradores, campesinos, sertanejos, tropeiros, ervateiros, peões e outras denominações não pejorativas (THOMÉ, p. 08, 1981).

${ }^{5}$ Unidos pela fé, 20.000 camponeses se insurgiram contra o Exército até serem massacrados, em 1915. Uma das rebeliões mais sangrentas do Brasil. O conflito, simultâneo à Primeira Guerra 
Mundial, foi esquecido pela imprensa da época e minimizado pelos livros de História. Ninguém sabe nem sequer quantos morreram. Podem ter sido 10.000 ou 20.000 (ANGELO, 2000).

${ }^{6} \mathrm{O}$ nascedouro do litígio surge na indefinição limítrofe provincial de São Paulo com Santa Catarina. Com a Guerra dos Farrapos (Rio Grande do Sul - 1835 a 1845), o governo imperial rompe a relação dos liberais gaúchos com os liberais paulistas criando uma nova província em 1853 - Paraná -, sem a definição de limites precisos: "Esta é a raiz mais antiga da contestação de terras pelos estados do Paraná e de Santa Catarina" (SANTOS, 2009, p.22).

${ }^{7}$ À época da conquista do litoral sul deste país, o atual território de Santa Catarina era habitado por silvícolas. Esses se dividiram em várias tribos, que por sua vez se subdividiram em vários grupos locais. O litoral de Santa Catarina era dominado pelos Carijós; entre o litoral e o planalto, nas florestas que cobriam os vales e as serranias, viviam os Xokleng; no planalto, na zona oeste, os Kainíani eram os senhores dos campos (THOMÉ, p. 25, 1981).

${ }^{8}$ Desde o início da colonização da região Sul, em 1725, negros compuseram a frota de João Magalhães. Passaram a ser empregados no cuidado da lavoura de subsistência, mas também como tropeiros, serviçais em pousadas, criados e trabalhadores domésticos em estâncias (CARDOSO, 2003, pp. 59, 60; VINHAS DE QUEIROZ, 1981, p. 23).

${ }^{9}$ O substantivo masculino "monge" não se refere ao religioso que habita um mosteiro, mas ao epíteto atribuído pelos moradores do sul do Brasil aos anacoretas, andarilhos e curandeiros com fama de santo (CABRAL, p. 107-198, 1979). A forte ascendência portuguesa dos caboclos pautada na crença do sebastianismo lusitano. Assim, a população revelava expressões de messianismo e de muito misticismo, considerando a ausência quase total da Igreja Católica.

${ }^{10} \mathrm{O}$ nome do município foi uma homenagem ao General Gustavo Lebon Régis, que na Campanha do Contestado entre 1912 e 1916, era Secretário Geral do Estado de Santa Catarina e ordenou o primeiro ataque a Taquaruçu, um dos maiores redutos caboclos (PMLR, 2016).

${ }^{11}$ Através de deslocamento de posseiros é que a sociedade nacional, isto é, branca se expande sobre os territórios tribais (MARTINS, P. 74-75, 1980).

${ }^{12}$ A agricultura de subsistência é uma nomenclatura ultrapassada, considerando que naquela realidade imperava uma agricultura de Autoconsumo, em que o caboclo visava à manutenção vital do seu núcleo familiar.

${ }^{13} \mathrm{O}$ coronelismo explora seu poderio ordenadamente: “(...) primeiramente suas milícias particulares, posteriormente seu prestígio socialmente reconhecido, e, por fim, o controle do eleitorado" (TOMPOROSKI, p. 10, 2011).

${ }^{14}$ Envolve diversos pontos de vistas, é definido por estudiosos como "insurreição xucra" ou "guerra civil"; para religiosos, ocorreu uma "rebelião de fanáticos"; para sociólogos, houve um "conflito social"; para antropólogos, foi um "movimento messiânico"; para políticos, uma tentativa de desestabilização das oligarquias; para administradores públicos, aconteceu uma "questão de limites"; para militares, tratou-se de uma "campanha militar"; para socialistas, aconteceu uma "luta pela terra". Entretanto, para historiadores regionais da atualidade, a Guerra do Contestado foi tudo isso simultaneamente (THOMÉ, 1981).

${ }^{15}$ Santa Catarina divide-se em 21 microrregiões cada uma representando uma Associação de Municípios. Lebon Régis/SC pertence à AMARP - Associação dos Municípios do Alto Vale do Rio do Peixe, entidade registrada como personalidade jurídica de direito privado e reconhecida de utilidade pública (LUDKA; FRAGA, 2015).

${ }^{16}$ Fonte: IBGE. Diretoria de Pesquisas - Coordenação de População e Indicadores Sociais COPIS.

17 É uma das ferramentas do Sistema de Indicadores, que tem como objetivo avaliar os municípios segundo seu nível de desenvolvimento sustentável. Esta ferramenta busca auxiliar os agentes públicos a se situar em relação a um cenário futuro desejável e a definir prioridades locais visando à conquista de patamares mais elevados de sustentabilidade e bem-estar social (IDMS, 2016).

${ }^{18}$ [...] fenômeno mundial, que aparece quando o principal meio para vencer as distâncias era a tração animal. A atividade tropeira pertence á época das trilhas em lugar das estradas, quando os rios eram vadeados por passos e a produção dos agricultores precisava de transporte rápido a distantes centros consumidores (FLORES, 1995, p. 135). 
$\overline{{ }^{19} \text { Esse costume de criação, comum a toda região de Floresta de Araucária, como aponta Man }}$ Yu Chang (1988, p. 37), "era condizente com o ambiente natural. O meio farto provia de alimentos silvestres em abundância, o que poupava aos criadores os custos de trato da criação". Se a criação era solta, a roça era cercada para evitar a invasão dos animais, pois ocupava menos espaço, uma vez que esta era destinada principalmente à subsistência.

${ }^{20}$ Desde meados do século XIX o mate já recebe uma visão industrial-mercadológica, com as explorações da matéria-prima no Planalto Catarinense. No ano de 1902, o mate participou com cerca de 3\% do valor total das exportações brasileiras. As regiões dos ervais localizam de Campo Alegre a Canoinhas, que foi a principal fornecedora de matéria-prima para a fabricação do mate (Mafra, 2008).

${ }^{21}$ [...] o caboclo sertanejo de Curitibanos é forte, sadio, sombrio, corajoso, delicado no trato, mas como todas as raças mescladas, vingativo até o exagero. Morador de um sertão medonho, onde a civilização só começou a penetrar depois da construção da estrada de ferro, o caboclo foi recebendo dessa civilização somente aquilo que os repudiados por Ella podiam oferecer: vícios e crimes (VIEIRA, 1918 p. 01).

${ }^{22}$ A empresa instituiu um processo industrial altamente mecanizado com grande organização técnica. O ponto de partida era o corte das toras no meio da floresta, tarefa realizada por grupos de trabalhadores que se embrenhavam nas matas, selecionavam e serravam as árvores. Em seguida, as toras que jaziam no chão eram presas por longos cabos de aço com centenas de metros de extensão e içadas por guinchos movidos a vapor comprimido. As toras gigantescas eram arrastadas até a margem dos ramais ferroviários construídos pela própria empresa, que poderiam atingir até trinta quilômetros de extensão. Ao serem arrastadas, destruíam toda a vegetação que estivesse em seu caminho, árvores menores, espécies economicamente menos interessantes e também grandes quantidades de árvores de erva mate, cuja extração era um elemento fundamental de sobrevivência para a população pobre que habitava a região. Após chegar a beira dos trilhos, o mesmo guincho erguia as toras e as colocava sobre vagões que eram conduzidos até o engenho da serraria, no centro da vila de Três Barras. No engenho, as toras eram serradas, selecionadas e armazenadas mecanicamente. Em seguida, eram carregadas em vagões e levadas até os portos de São Francisco do Sul e Paranaguá para exportação (TOMPOROSKI, p. 03, 2011).

${ }^{23}$ Os caboclos de Santa Catarina formavam o bravo "Exército Encantado de São João Maria", unindo sob a cruz verde da bandeira branca da libertação quase 10 mil pessoas armadas homens, velhos e mulheres [...] [...] Tiveram a ousadia respondida a bala. Lutaram pela sobrevivência até que, cercados, sucumbiram aos mais fortes - O GENOCÍDIO (FRAGA, p. 07, 2015).

${ }^{24} \mathrm{O}$ Contestado virou um labirinto verde, desafiando os caboclos e suas tentativas de guardar as memórias de família e de comunidade. As porteiras de aço das companhias produtoras de pinus 12 predominam, bloqueando caminhos seculares ainda do tempo dos viajantes e tropeiros, que percorriam trilhas do Planalto Catarinense, com seus muares, fazendo o percurso das estâncias do Rio Grande do Sul à tradicional feira de bois de Sorocaba, vila da então capitania e depois província de São Paulo (NOSSA \& JÚNIOR, 2012).

${ }^{25}$ O Ministério do Desenvolvimento Social e Combate à Fome é responsável pelas políticas nacionais de desenvolvimento social, segurança alimentar e nutricional, assistência social e de renda de cidadania (MDS, 2016).

${ }^{26}$ O Cadastro Único para Programas Sociais do Governo Federal (Cadastro Único) é um instrumento que identifica e caracteriza as famílias de baixa renda, permitindo conhecer melhor suas realidades socioeconômicas (MDS, 2016).

${ }^{27}$ Instrumento que mede a concentração de renda, apontando a diferença entre a renda dos mais pobres e dos mais ricos. Numericamente, varia de zero a um, em que zero representa a situação de igualdade, ou seja, todos têm a mesma renda, restando o valor um no extremo oposto, ou seja, uma só pessoa detém toda a riqueza (IPEA, 2016).

${ }^{28}$ Conhecido por Índice de Pobreza Humana (IPH), este indicador criado pela ONU em 1997 para medir a pobreza humana utiliza-se no seu cálculo três dimensões base: longevidade; conhecimento e nível de vida. 


\section{Bibliografia}

ANGELO, C. Guerra do Contestado: A guerra que o Brasil esqueceu. Revista Super Interessante, abril de 2000. Disponível em: http://super.abril.com.br/superarquivo/2000/cont eudo_128118.shtml. Acesso em 07 Fev. 2016.

BRANDT, M. Criação de porcos "à solta" na floresta ombrófila mista de Santa Catarina: paisagem e uso comum da terra. História [online]. 2015, vol.34, n.1, pp. 303322. Disponível em: http://www.scielo.br/scielo.php?script=sci_arttext\&pid=S010190742015000100303\&lng =pt\&nrm=iso\&tlng=en\#aff1. Acesso em 12 fev. 2016.

BRASIL. Ministério de Desenvolvimento Social e Combate à Fome (MDS). Bolsa Família - 2016. Disponível em: http://mds.gov.br/. Acesso em 13 fev. 2016.

CABRAL, Oswaldo Rodrigues. A campanha do Contestado. Florianópolis: Lunardelli, 1979.

CARDOSO, Fernando Henrique. Capitalismo e Escravidão no Brasil Meridional. Rio de Janeiro: Editora Civilização Brasileira, 2003.

CHANG, M. Y. Sistema faxinal: uma forma de organização camponesa em desagregação no Centro-Sul do Paraná. Londrina, IAPAR, 1988. 123p. (IAPAR, Boletim técnico, 22).

CONCEIÇÃO, E.N. A Saga do Contestado - Histórias de Santa Catarina - em Quadrinhos. Florianópolis: Governo de Santa Catarina, 2004.

FERREIRA FILHO, A. História Geral do Rio Grande do Sul. Porto Alegre: Globo, 1978.

FLORES, M. O Tropeirismo e a Economia Colonial. In: SANTOS, L. M. S.;VIANNA, M. L. C.; BARROSO, V. L. M. (orgs) Bom Jesus e o Tropeirismo no Brasil Meridional. Porto Alegre: EST, 1995.

FRAGA, N. C. Serra da Boa Esperança, geografias de um território revisto e (re)sentido do Contestado. Disponível em: http://desacato.info/serra-da-boa-esperanca-geografiasde-um-territorio-revisto-e-resentido-do-contestado/. Acesso em 16 fev. 2016.

FRAGA, N. C. Território e silêncio. Contributos reflexivos entre o empírico e o teórico. In FRAGA, N. C. (Org). Territórios e Fronteiras: (Re) Arranjos e Perspectivas. Florianópolis: Insular, 2011.

FRAGA, N. C. (Org.). Contestado, o território silenciado. Florianópolis, Ed. Insular, 2009.

FRAGA, N. C. Contestado: A Grande Guerra Civil Brasileira. In: REZENDE, C. J.; TRICHES, I. Paraná, Espaço e Memória - diversos olhares histórico-geográficos. Curitiba: Ed. Bagozzi, 2005, p. 228-255.

FRAGA, N. C. Mudanças e permanências na rede viária do contestado: uma abordagem acerca da formação territorial no Sul do Brasil. Tese de Doutorado. Universidade Federal do Paraná, 2006.

FRAGA, N. C. Vale da Morte: O Contestado visto e sentido. Entre a cruz de Santa Catarina e a espada do Paraná. Blumenau: Ed. Hemisfério Sul, 2010.

FRAGA, N. C. Guerra do Contestado: causas, interesses e possibilidades de pensar um povo se levantando contra a tirania - uma contribuição aos que iniciam seus estudos sobre o Contestado. Centro de Pesquisa e Apoio aos Trabalhadores - CEPAT. Centro Jesuíta de Cidadania e Ação Social - CJ-Cias e Integra a Rede Jesuíta de Cidadania e Ação Social - SJ-Cia. Curitiba/PR, 2015. Disponível em> http://pt.slideshare.net/serginhosucesso/guerra-do-contestado-49888532. Acesso em 12 fev. 2016.

GOULART, J. A. Meios e instrumentos de transporte no interior do Brasil. Rio: MEC, 1959. 
IBGE - Instituto Brasileiro de Geografia e Estatística. Censo Demográfico 2010. Disponível em: http://www.censo2010.ibge.gov.br. Acesso em 07 fev. 2016.

IDMS - ÍNDICE DE DESENVOLVIMENTO MUNICIPAL SUSTENTÁVEL. Disponível em: http://indicadores.fecam.org.br/cms/pagina/ver/codMapaItem/621. Acesso em 07 fev. 2016.

LEMOS, S. T. F. A face oculta do caboclo de Curitibanos, Santa Catarina, perdas e rupturas em sua peregrinação da economia de subsistência para o trabalho precarizado. 2006. 236 f. Tese (Doutorado em Serviço Social) - Pontíficia Universidade Católica de São Paulo, São Paulo, 2006.

LEMOS, Z. A. Curitibanos na história do Contestado. 2 ed. Curitibanos SC: Impressora Frei Rogério, 1983.

LUDKA, V. M.; FRAGA, N. C. Fome e pobreza na Região do Contestado Catarinense: conflitos do desenvolvimento no Sul do Brasil. In: Encontro Nacional da ANPEGE, $11^{\circ}$, 2015. Presidente Prudente. Anais. UNESP: 2015, p. 4291-4302.

MAFRA, A. D. Aconteceu nos Ervais: A disputa territorial entre Paraná e Santa Catarina pela exploração da erva-mate - região sul do Rio Negro. 2008. $150 \mathrm{f}$. Dissertação (Mestrado em Desenvolvimento Regional) - Universidade do Contestado, Canoinhas, 2008.

MARTINS, J. S. Expropriação e violência. São Paulo: Hucitec, 1980.

NOSSA, L. \& JÚNIOR, C. Esquecida, região ainda vive em clima de miséria. In: Meninos do Contestado, 11 de fevereiro de 2012 - Estado de S. Paulo. Disponível em: http://topicos. estadao.com.br/contestado. Acesso em 08 fev. 2016.

PMLR - PREFEITURA MUNICIPAL DE LEBON RÉGIS. Disponível em: http://www.lebon regis.sc.gov.br/. Acesso em 07 fev. 2016.

SALOMÃO, E. R. A Guerra de S. Sebastião (1912-1916): um estudo sobre a ressignificação do mito do rei encoberto no movimento sociorreligioso do contestado. 2012. 292 f. Tese (Doutorado em História) - Universidade de Brasília, Brasília, 2012.

RITTER, M. L. As Sesmarias do Paraná no Século XVIII. IHGEP, Estante Paranista 9. Curitiba: IHGEP, 1980.

ROSSETO, S. Histórica da Região Oeste. CEOM, v. 1 (1986) e reeditado no v. 4, (1989).

SANTOS, S. C. Novas Histórias de Santa Catarina. Florianópolis, Ed. Do Autor, 124 p., 1974.

SANTOS, W. Contestado: A guerra dos equívocos. O poder da fé. Vol. I. Rio de Janeiro: Record, 2009.

SCHÜLLER S. O. Taipas, origem do homem do Contestado: o caboclo. Florianópolis SC, Letras Contemporâneas, 2000.

THOMÉ, N. Civilizações primitivas do Contestado. Caçador SC: Impressora Universal, 1981.

THOMÉ, N. Caminhos de tropeiros nos séculos XVIII e XIX como fatores pioneiros de desbravamento do contestado. Revista Eletrônica do Programa de Mestrado em Desenvolvimento Regional da Universidade do Contestado. Ano 2, n. 1, jul. 2012.

TOMPOROSKI. A. A. Entre o patrão e o coronel: A atuação da Lumber Company e as disputas políticas no pós-Contestado, 1917-1920. Anais do XXVI Simpósio Nacional de História - ANPUH. São Paulo, julho 2011.

VIEIRA DA ROSA, J. Chorographia de Santa Catarina. Florianópolis: Typographia da Livraria Moderna, 1905. 